\title{
The Remobilization of the Propaganda and Morale Network, 1947-1953
}

\author{
Jeff Pooley \\ Muhlenberg College \\ pooley@muhlenberg.edu
}

Draft 2018-07-25

In the aftermath of World War II, the U.S. social scientists serving in Washington and abroad returned-most of them-to their universities. A large share of those returnees had staffed the U.S. government's sprawling propaganda and morale bureaucracies. Shuffling between agencies, these scholars-on-loan forged informal ties and something like a network. Back on campus, they resumed teaching and research. A raft of published work based on wartime projects soon appeared, under a label-"communications research"-that had taken hold during the war. ${ }^{1}$ But few of the returning social scientists identified with the new field. Anthropologists returned to anthropology, sociologists to sociology, and so on.

The thesis of this paper is that the Cold War brought them back together. The new national security state, in other words, recruited a remarkably similar cast of social scientists to run its propaganda research initiatives. Some of those projects were self-conscious revivals of World War II efforts, but even the fresh initiatives were staffed by veterans of the earlier campaigns. The mix of military, civilian, and foundation sponsors in the early Cold War, moreover, resembled the WW II configuration. The propaganda and morale network was, in effect, remobilized.

The first mobilization is widely considered a pivotal moment in the history of U.S. social science, one that reverberated for decades. The second mobilization-in full swing from 1949 until the Korean armistice in 1953-is rarely invoked in these terms. One of this paper's claims is that the second enlistment was crucial too, if only because the lessons of the war were institutionalized in these years. Yoked together again, around a similar set of propaganda and morale problems, scholars used the funded, networked projects to re-enact, and in some cases formalize, their intoxicating World War II experience. The vanguardist "behavioral sciences" movement-a vision forged in World War II service-was neither named nor established until

1 Four postwar edited volumes help register the new interest in "communications research": Lyman Bryson, ed., The Communication of Ideas (New York: Harper, 1948); Wilbur Schramm, ed., Communications in Modern Society (Urbana: University of Illinois Press, 1948); Paul F. Lazarsfeld and Frank N. Stanton, eds., Communications Research, 1948-1949 (New York: Harper, 1949); and Schramm, ed., Mass Communications (Urbana: University of Illinois Press, 1949). 
this early Cold War period.2 The blueprints, in other words, were drafted in the first half of the decade, but only built out years later against the new, Cold War backdrop.

The traits that we associate with the behavioral sciences-methodological ambition, general theory, team projects, aspirational mathematics, and the commingling of applied and basic research ${ }^{3}$-these were promoted under the banner of hearts-and-minds persuasion research, to a surprising extent. The big social science of the early 1950s depended on the military, the State Department, and allies in the foundation world. Military funders like the Office of Naval Research (ONR) underwrote a range of social science projects, as did Rockefeller and its peers. ${ }^{4}$ But a large share of these grants and projects were motivated by morale and propaganda questions in the shadow of the Cold War threat. And their practical effect was to re-establish World War II networks that had, in the postwar interregnum, gone half-dormant.

My approach, given the sheer scale of the social science enlistments involved, was to generate a high-altitude overview of the two periods and their interregnum. The point was to synopsize the vast secondary literature, with an emphasis on the cross-cutting dynamism that characterized, and linked, the eras.

For the bird's-eye view, I drew upon the published historiography to compile a database of social science activity over the relevant period. The propaganda bureaucracies of wartime Washington were makeshift enterprises, staffed by a peripatetic cast of full-time staff and consultants. 5 Congressional interventions and the vagaries of war made for rapid turnover, abrupt re-organization, and even closure. To track these personnel changes, I used a relational database to track "stints" - the duration of a scholar's affiliation with a given organization or an event or short-term project. ${ }^{6}$ Each record, in other words, links a scholar to an institution (like the Office of War Information) or a project (like the Totalitarian Communications Research Project at the New School). Every record, crucially, tracks the duration of the affiliation in question, with the aim to register changes over time.

2 Hunter Crowther-Heyck, "Patrons of the Revolution: Ideals and Institutions in Postwar Behavioral Science," Isis 97, no. 3 (2006); and Jefferson D. Pooley, "A 'Not Particularly Felicitous' Phrase: A History of the 'Behavioral Sciences' Label," Serendipities: Journal for the Sociology and History of The Social Sciences 1, no. 1 (2016).

3 Hunter Crowther-Heyck, Herbert A. Simon: The Bounds of Reason in Modern America (Baltimore: Johns Hopkins University Press, 2005), chap. 5.

$4 \quad$ Mark Solovey, Shaky Foundations: The Politics-Patronage-Social Science Nexus in Cold War America (New Brunswick, NJ: Rutgers University Press, 2015), chaps. 2-3.

5 See, e.g., Jean M. Converse, Survey Research in the United States: Roots and Emergence, 1890-1960 (Berkeley: University of California Press, 1987), chap. 5.

6 The relational database was created using AirTable, and can be viewed (though not edited) at https://airtable.com/ shrkJ6AFUPeBojCo2/tblAUg0zbk21Be08f. 
Documentation for each "stint" is drawn from a second database: a large collection of secondary literature on the history of social science. The literature centers on the middle-third of the twentieth century, though the database also includes books and articles that treat longer time spans as well as archival and published "primary" work from the period. I used the database program DevonThink to generate a full-text, searchable index of already-digitized books and articles along with newly scanned publications. (The latter were processed with optical character recognition (OCR) software.) DevonThink's granular search capability (including a "near" function that can locate phrases within a specified word range) afforded search by organization, event, and/or scholar in various combinations. These searches yielded citable evidence for each "stint": in every case I copied the passage to the relevant record, including the citation, page number, and a url link-back to the original PDF document. The database includes over 1,500 articles and books that treat the history of U.S. social science over the relevant period.

The stints were used to build year-by-year snapshots of the evolving networks, with the aim to capture the cross-pollination among the deployed academics over time. These relationships are represented in annual network maps, beginning in 1937 through to 1953 (see Figures 1 through 17). 7 Taken in succession, the maps function as a motion-capture device, animating the movement of scholars as well as the emergence, shuttering, and, in some cases, re-emergence of their affiliated institutions. The story told by these maps, and supported by a narrative account, is of an enduring network, mobilized for World War II and re-drafted to face the Soviet enemy.

\section{The First Mobilization}

The U.S. wartime engagement in propaganda research came in a pair of graduated steps. The first phase stretched from the September 1939 invasion of Poland to the Pearl Harbor attack in late 1941, a period when the Roosevelt Administration delegated the task of erecting the infrastructure of morale-building, propaganda analysis, and listening posts to the Rockefeller Foundation. Official federal initiatives were not yet feasible in political terms, owing to isolationist sentiment in Congress. ${ }^{8}$ Only the Japanese surprise attack permitted the

7 The maps were created using the cloud-based network analysis software Polinode (polinode.com).

8 The best account of the Rockefeller mobilization is Brett Gary, "Communication Research, the Rockefeller Foundation, and Mobilization for the War on Words, 1938-1944," Journal of Communication 46, no. 3 (1996): 124-48. 
administration to nationalize-in the second, dramatically expanded phase-the foundation's private propaganda research campaign. 9

The scholars who staffed the surrogate Rockefeller effort would go on to form the nucleus of the federal operation. Indeed, many of these figures - including Hadley Cantril, Paul Lazarsfeld, Harold Lasswell, Geoffrey Gorer, Lloyd Free, Hans Speier, and Leonard Doob-would occupy prominent posts in the early Cold War reprise as well. It is a telling irony that a private philanthropy set in motion an apparatus that would, in the late 1940s, serve as the research adjunct to the new national security state.

John Marshall, the head of Rockefeller's Humanities Division, organized the foundation's bureaucracy-in-waiting in the late 1930s. ${ }^{10}$ His initial interest had been in educational broadcasting, in the bitter aftermath of the Communication Act of 1934. He and the foundation, in the wake of the Act, had seeded a series of university projects intended to carve out space for educational content within the commercial system the Act had established. ${ }^{11}$ With the outbreak of war in Europe, he engineered a sharp pivot to propaganda research-by repurposing existing efforts and establishing a slew of new initiatives.

The following year-by-year account picks up the story in 1937, when major Rockefeller initiatives took hold, through to the rapid demobilization of the federal government's propaganda bureaucracy after V-J Day in fall 1945. Each annual capsule records the moralerelated endeavors that got started, transformed, or shuttered, along with the affiliations and movements of relevant social scientists.

9 There is a large literature on the U.S. government's wartime propaganda-research bureaucracy. For an overview, see Gene M. Lyons, The Uneasy Partnership: Social Science and Federal Government in the Twentieth Century (New York: Russell Sage Foundation, 1969), chap. 4; Converse, Survey Research, chaps. 5-7; Ellen Herman, The Romance of American Psychology: Political Culture in the Age of Experts (Berkeley: University of California Press, 1996), chap. 4; and Ido Oren, Our Enemies and US: America's Rivalries and the Making of Political Science (Ithaca, NY: Cornell University Press, 2013), chap. 2.

On John Marshall's remarkable, and under-appreciated, centrality for the nascent fields of communications research, see J. Michael Sproule, Propaganda and Democracy: The American Experience of Media and Mass Persuasion (New York, NY: Cambridge University Press, 1997), 74-75; Brett Gary, The Nervous Liberals: Propaganda Anxieties from World War I to the Cold War (New York: Columbia University Press, 1999), 85-89; and William J. Buxton, "Reaching Human Minds: Rockefeller Philanthropy and Communications, 1935-1939," in The Development of the Social Sciences in the United States and Canada: The Role of Philanthropy, ed. Theresa R. Richardson and Donald Fisher (Stamford, Conn: Ablex Pub. Corp, 1999). Economics, ed. Robert E. Babe (Boston: Kluwer Academic Publishers, 1994). 


\section{FIGURE ONE}

A pair of significant Rockefeller-backed institutions got underway in 1937: the Princeton Radio Research Project and The Public Opinion Quarterly journal. Both projects were rooted in Marshall's effort to underwrite research into radio audiences-on his theory that audience data could justify, to the commercial networks, the draw of educational programming. ${ }^{12}$ Marshall's move to seed the initiatives coincided with social scientists' embrace of new sampling-based survey techniques, in the wake of George Gallup's high-profile 1936 triumph over the much larger Literary Digest straw poll.13 The Rockefeller funding and coordination helped bring together a small community of self-styled "public opinion" researchers, comprised of political scientists, psychologists, sociologists, and commercial pollsters. They were bound by surveyresearch methods, the study of media audiences, and the Rockefeller-backed institutions that supported both. ${ }^{14}$

The Princeton Radio Research Project was launched by Princeton psychologist Hadley Cantril and CBS researcher Frank Stanton; the pair recruited Austrian emigré Paul Lazarsfeld to direct the Project. Lazarsfeld, working with fellow emigrés and other young researchers, produced an avalanche of media-audience studies in the Project's frantic first two years. ${ }^{15}$ Around the same time, The Public Opinion Quarterly published its first issue, with Princeton political scientists DeWitt Clinton Poole and Harwood Childs as top editors. The journal's associate editors were Cantril, the journalist O.W. Riegel, and political scientists Harold Lasswell (Chicago) and Pendleton Harring (Harvard). ${ }^{16}$ Each editor, as well as many authors published in the journal's first volume-including Lazarsfeld, historian Merle Curti, pollsters Elmo Roper and Archibald Crossley, psychologist Theodore Newcomb, political scientists Leo Rosten and Bruce Lannes Smith, journalism scholars Ralph Casey and Fred Siebert, and anthropologist Margaret Meadwould take up significant posts in the wartime propaganda effort.

12 Buxton, "The Political Economy," 160-167; Converse, Survey Research, 82; and Gary, "Communication Research," 132. The Public Opinion Quarterly was conceived in 1935, but launched in 1937 with Marshall's Rockefeller support. See Harwood L. Childs, “The First Editor Looks Back," Public Opinion Quarterly 21, no. 1 (1957): 7-9.

13 Converse, Survey Research, 114-127; and Susan Ohmer, George Gallup in Hollywood (New York: Columbia University Press, 2012), 51-63.

14 For a much more detailed account of public opinion research as a late interwar cluster and nascent network, underwritten by Rockefeller's Marshall, see Jefferson Pooley, "An Accident of Memory: Edward Shils, Paul Lazarsfeld and the History of American Mass Communication Research” (Ph.D. Dissertation, Columbia University, 2006), 216-48.

15 See David E. Morrison, The Search for a Method: Focus Groups and the Development of Mass Communication Research (Luton, UK: University of Luton Press, 1998), 68-83; Jefferson D. Pooley and Michael Socolow, "Checking Up on The Invasion from Mars: Hadley Cantril, Paul Lazarsfeld, and the Making of a Misremembered Classic," International Journal of Communication 7 (2013); and Paul F. Lazarsfeld, "An Episode in the History of Social Research," in The Intellectual Migration: Europe and America, 1930-1960, ed. Bernard Bailyn and Donald Fleming (Cambridge, MA: Harvard University Press, 1969), 304-30. 


\section{8}

\section{FIGURE TWO}

Lazarsfeld's radio-research operation continued to mine audience data, much of it from the Project's CBS-affiliated associate director Frank Stanton, and rushed to analyze the apparent panic after Orson Welles' late 1938 "War of the Worlds" broadcast. ${ }^{17}$ Meanwhile, Marshall underwrote another media-research initiative, the American Film Center (AFC), based in New York City and headed by psychologist Donald Slesinger and staffed by British anthropologist Geoffrey Gorer. ${ }^{18}$ The Public Opinion Quarterly maintained its role as the published crossroads for the congealing network of public opinion researchers, with 1938 contributions from Gallup, psychologists Edgar Dale, Clyde Miller, and Daniel Katz, sociologists Lazarsfeld and Marjorie Fiske, and political scientists Lasswell, Herring, and Poole.

Though many of Marshall's media-related disbursements remained oriented to education and uplift-including funds for the Museum of Modern Art's Film Library ${ }^{19}$-he was already conceiving of the foundation's film and radio investments in propaganda terms. In a remarkable 1938 memo on "Next Jobs in Film and Radio," Marshall outlined a Rockefeller campaign, supported by social scientists, of "democratic propaganda" to combat "collectivism": "To establish such a propaganda actually might be an important first step," he wrote, "in establishing the legitimate influence of radio and film in a society like ours."20

Late in the year, Marshall proposed a series of conferences centered on the prospects for the public's media-led education, slated for 1939.21

17 On the conflict of authorship between Lazarsfeld, Cantril, and Lazarsfeld's wife Herta Herzog, see Jefferson Pooley and Michael Socolow, "War of the Words: The Invasion from Mars and Its Legacy for Mass Communications Scholarship," in War of the Worlds to Social Media: Mediated Communication in Times of Crisis, ed. Joy Elizabeth Hayes, Kathleen Battles, and Wendy Hilton-Morrow (New York: Peter Lang, 2013).

18 Haidee Wasson, "Hollywood Bypass: MoMA, the Rockefeller Foundation, and New Circuits of Cinema," in Patronizing the Public: American Philanthropy's Transformation of Culture, Communication, and the Humanities, ed. William Buxton (Lanham, MD: Lexington Books, 2009), 108; and Buxton, "Reaching Human Minds," 186; Charles R. Acland, "Screen Technology, Mobilization, and Adult Education in the 1950s ," in Patronizing the Public: American Philanthropy's Transformation of Culture, Communication, and the Humanities, ed. William Buxton (Lanham, MD: Lexington Books, 2009), 262-63; and Gary, Nervous Liberals, 110-115.

19 David Culbert, "The Rockefeller Foundation, the Museum of Modern Art Film Library, and Siegfried Kracauer, 1941," Historical Journal of Film, Radio and Television 13, no. 4 (1993): 495-96, doi:10.1080/01439689300260381.

20 John Marshall, "Next jobs in radio and film," August 31, 1938, folder 50, box 5, series 911, RG 3, Rockefeller Foundation Archives, Rockefeller Archive Center, 5-8. 


\section{9}

\section{FIGURE THREE}

The foundation's trustees agreed to fund the conference series in August 1939, just before the outbreak of war. When the first meeting took place a month later, the Nazi conquest of Central Europe was already underway. The conferences' original purpose, to "develop a disciplined approach to the study of mass communication," was joined by a second agenda: to design an extra-governmental plan for combating German propaganda and mobilizing war support. Over the next year, Marshall and the social-scientist participants - the meetings only later came to be called the "Communications Seminar" or, less often, the "Communications Group"-guided the effort to redeploy the foundation's existing projects and stable of funded scholars to the European war. ${ }^{22}$

The Seminar's roster drew heavily on the nascent public opinion field: political scientists Harold Lasswell and Lloyd Free, sociologists Paul Lazarsfeld and Robert Lynd, psychologists Donald Slesinger and Hadley Cantril, library scientists Douglas Waples, and anthropologist Geoffrey Gorer. The other non-foundation participants were educationalist Lyman Bryson, BBC analyst Charles Siepmann, and literary theorist I. A. Richards. The group's ten meetings over the next 15 months were largely concerned with the role that members' communication expertise might play in the inevitable state-managed "emergency psychology" campaign to come.23

In coordination with that effort, Rockefeller seeded a pair of shortwave-radio "listening centers," one at Princeton and the other at Stanford-the direct predecessors of the federal government's Foreign Broadcast Intelligence Service, established in late 1941.24 The Princeton Center was run by Harold Graves, and staffed by Public Opinion Quarterly editor Harwood Childs, political scientist John Whitton, and psychologist Jerome Bruner, with consulting from Lloyd Free. 25

Just before the Seminar's first meeting, psychologist Rensis Likert was tapped to direct a small survey-research unit inside the Department of Agriculture, renamed the Division of Program

22 For detailed accounts of the Seminar's activities, see Gary, "Communication Research," 129-142; and Pooley, "An Accident of Memory," 238-249.

23 Gary, "Communications Research," 131-32. At the May meeting, Marshall declared: "In a period of emergency such as I believe we now face, the manipulation of public opinion to meet emergency needs has to be taken for granted. In such a period, those in control must shape public opinion to support courses of action which the emergency necessitates... No one, I think, can blame them for that impulse." Quoted in Ibid., 139.

24 Sproule, Propaganda and Democracy, 185; Harold N. Graves, War on the Short Wave (New York: Foreign Policy Association, 1941), 64; and Joseph E. Roop, Foreign Broadcast Information Service History Part I: 1941-1947 (Langley, VA: Central Intelligence Agency, 1969), 5-6. 
Surveys on Likert's arrival.26 Over the war years the Division would go on to act as a survey research shop-for-hire, contracting for a number of major agencies including the Office of War Information and Department of the Treasury.27 Among the many significant scholars who worked for Likert's Program Surveys operation during the war were Dorwin Cartwright, Jerome Bruner, E. R. Hilgard, Herbert Hyman, Ruth Tolman, and Angus Campbell. ${ }^{28}$

\section{0}

\section{FIGURE FOUR}

In 1940, Marshall's Seminar issued a pair of 1940 reports calling for war-related opinion management: "We believe," read the first, "that for leadership to secure that consent will require unprecedented knowledge of the public mind and of the means by which leadership can secure consent." 29 Even as the Seminar's final fall 1940 report was distributed to scholars, university presidents, foundation officers, publishers, and government officials, Marshall and Lasswell were approaching government officials to delicately state that foundation funds were available for propaganda-related research. ${ }^{30}$ From early 1940 until the U.S. entry into the war in December 1941, the Foundation served, in essence, as an unofficial arm of the state when the Roosevelt administration-hampered by a public culture still wary of propaganda, and a somewhat isolationist Congress - could not feasibly do so itself.

By the end of 1940, the Foundation had set up and funded an elaborate bundle of propagandarelated projects, with existing initiatives brought into the propaganda fold. ${ }^{31}$ Marshall directed funds to library scientist (and Seminar member) Douglas Waples' Reading Research Project at the University of Chicago, which also engaged Waples' ambitious student Bernard Berelson. 32 Rockefeller funds also supported political scientist Leo Rosten's L.A.-based Motion Picture

26 Blair T. Johnson and Diana R. Nichols, "Social Psychologists' Expertise in the Public Interest: Civilian Morale Research During World War II," Journal of Social Issues 54, no. 1 (1998): 60; and Converse, Survey Research, 157-159.

27 Herbert H. Hyman, Taking Society's Measure: A Personal History of Survey Research (New York: Russell Sage Foundation, 1991), 4; Lyons, Uneasy Partnership, 90-93; and Converse, Survey Research, 172-174.

Donald G. Marquis, "Social Psychologists in National War Agencies.," Psychological Bulletin 41, no. 2 (1944): 116-17. A number of others served as consultants, including Gordon Allport, Kurt Lewin, and Gardner Murphy. Ibid., 117.

"Research in Mass Communications," July 1940, quoted in Gary, "Communications Research," 139. Richards had resigned over methodological differences in early 1940, while Bryson and Siepmann issued notable dissents. Pooley, "An Accident of Memory," 244-246.

Gary, "Communication Research," 142.

On the American Film Center's early 1940s propaganda pivot, see Gary, Nervous Liberals, 109-113. On the Museum of Modern Art's Film Library activity-including hosting emigré scholar Siegfried Kracauer study of Nazi film beginning in 1941 -see lbid., 115-118. 
Research Project. ${ }^{33}$ After a bitter falling-out with Cantril, Lazarsfeld moved the Radio Research Project to Columbia, while Marshall established Cantril in his own Princeton Office of Public Opinion Research. ${ }^{34}$ Cantril and his Princeton Office, occasionally using shell companies, would go on to provide survey data to Nelson Rockefeller's Office of the Coordinator for InterAmerican Affairs, and Franklin Delano Roosevelt himself. In the early 1940s Cantril's Princeton Office worked closely with Gallup, and employed psychologists Daniel Katz, Leonard Doob, and Jerome Bruner, political scientists Lloyd Free and Frederick Williams, and statistician Frederick Mosteller. ${ }^{35}$

Also in 1940, Marshall and the foundation funded the Totalitarian Communications Research Project at the New School for Social Research. The Project, run by emigré scholars Hans Speier and Ernst Kris, focused on content analysis of Nazi news bulletins. ${ }^{36}$ In an already frenetic year, Marshall arranged for Lasswell to set up his own content-analysis operation at the Library of Congress, the Experimental Division for the Study of War-Time Communications. ${ }^{37}$ Lasswell's Experimental Division would become a major center of social-scientific propaganda research over its four-year life-span, directly employing political scientists Ithiel de Sola Pool and Heinz Eulau, sociologists Nathan Leites, Morris Janowitz, and Joseph Goldsen, and psychologist Irving Janis, while training many others. The Rockefeller Foundation also supplied the startup funds for the Office of the Coordinator for Inter-American Affairs, headed by one of the family's heirs, Nelson Rockefeller, which would work closely with Cantril's new polling operation. 38

33 The Project, which worked to support Rosten's major Hollywood study, began in 1939 with Carnegie Corporation funds, with Rockefeller issuing its first grant in 1940. Lynd and Lasswell, along others, served on Rosten's advisory board. Johannes C. Gall, “An 'Art of Fugue' of Film Scoring: Hanns Eisler's Rockefeller Foundation-Funded Film Music Project (1940-1942) ," in Patronizing the Public: American Philanthropy's Transformation of Culture, Communication, and the Humanities, ed. William Buxton (Lanham, MD: Lexington Books, 2009), 133.

The Princeton Radio Research Project was also called, in its early years, the Office of Radio Research, and the latter name was retained for the new Columbia affiliation (which was initially quite tentative). On the Cantril-Lazarsfeld dispute and the Rockefeller-sponsored divorce, see Pooley and Socolow, "Checking up on The Invasion from Mars," 1934-1937.

35 See José Luis Ortiz Garza, "The Early Days of Survey Research in Latin America," in The Early Days of Survey Research and Their Importance Today, ed. Hannes Haas, Hynek Jarabek, and Thomas Peterson (Vienna: Braumüller, 2012); Hadley Cantril, The Human Dimension: Experiences in Policy Research (New Brunswick, NJ: Rutgers University Press, 1967); Converse, Survey Research, 165; and Herman, Romance of American Psychology, 333

Peter M. Rutkoff and William B. Scott, New School: A History of the New School for Social Research (New York: Free Press, 2009), 139-141; and Daniel Bessner, Democracy in Exile: Hans Speier and the Rise of the Defense Intellectual (Ithaca: Cornell University Press, 2018), 110-17.

38 Rockefeller's Office of the Coordinator began life as the Coordinator of Commercial and Cultural Relations for the American Republics, and changed names and government sponsors a number of times from 1940 to 1945. See Claude Curtis Erb, "Nelson Rockefeller and United States-Latin American Relations, 1940-1945" (PhD dissertation, Clark University, 1982); Cary Reich, The Life of Nelson A Rockefeller: Worlds to Conquer, 1908-1958 (New York: Doubleday, 1996), 165-261; Gary, Nervous Liberals, 173-74; and Ortiz Garza, "The Early Days of Survey Research," 144-49. 
Meanwhile, a number of social scientists joined the Committee for National Morale, a presidential advisory committee established in 1940 and charged with devising a wartime propaganda plan. Notable for its lack of Rockefeller funding, Committee members included a by-now familiar cast: Hadley Cantril, Gordon Allport, Leonard Doob, Margaret Mead, Geoffrey Gorer, and many others. ${ }^{39}$

\section{1}

\section{FIGURE FIVE}

The shadow Rockefeller bureacracy continued to operate throughout 1941, but with the Japanese attack in December and the subsequent declaration of war, the federal government began to nationalize the effort in earnest. Over the next three years a sprawling propaganda and morale apparatus was erected across at least a dozen government agencies. The campaign was complex and unstable, owing to frequent name changes, agency reassignments, and dramatic shifts in Congressional appropriations. The social scientists employed by propaganda-related organizations moved around themselves, and often maintained multiple affiliations as staffers or consultants. The core group of scholars was drawn from the Rockefeller-sponsored initiatives, but included many other social scientists drawn to Washington or London by the official U.S. entry to war. All the organizational and personnel shuffling from 1941 to 1945 generated a web of official and informal contacts-a crosspollination that, according to many postwar participant accounts, forged lasting networks that survived the postwar return to campus. 40 More to the point, those contacts - and the shared wartime service-made possible the Cold War remobilization to come.

The Rockefeller listening centers at Princeton and Stanford were essentially absorbed, in 1941, into the Foreign Broadcast Intelligence Service (FBIS), initially housed in the Federal Communications Commission (FCC). ${ }^{41}$ The already ubiquitous Lloyd Free-who, in 1939, had assumed the Public Opinion Quarterly managing editorship-was tapped as the FBIS's first director. Free was joined by the Princeton Listening Center's Harold Graves and Jerome Bruner. ${ }^{42}$ Until 1944, when Congressional cuts decimated FBIS, a remarkable collection of social scientists worked or consulted for the overseas-monitoring agency, including sociologists (Hans Speier, Edward Shils, and Nathan Leites), political scientists (Alexander

Sproule, Propaganda and Democracy, 181-82; and Herman, Romance of American Psychology, 49.

40 See, for example, John A. Clausen, "Research on the American Soldier as a Career Contingency," Social Psychology Quarterly 47, no. 2 (1984); Harold F. Gosnell and Moyca C. David, "Instruction and Research: Public Opinion Research in Government," American Political Science Review 43, no. 3 (1949); and Daniel Lerner, Sykewar: Psychological Warfare Against Germany, D-Day to VE-Day (New York: Stewart, 1949).

41 The FBIS was initially called the Foreign Broadcast Monitoring Service, but changed its name after a few months. Roop, Foreign Broadcast Intelligence Service, 8-12, 50. 
George and Sebastian de Graza), psychologists (Goodwin Watson, John Gardner, Otto Klineberg, and Theodore Newcomb), and library scientist Bernard Berelson;43 even Rockefeller's John Marshall consulted for the agency. 44

The Office of the Coordinator of Information (COI), headed by lawyer William Donovan, was also created in 1941, with the charge to manage the already octopus-like propaganda bureacracy. 45 Donovan's Office was the precursor to the Office of Strategic Services-itself the forerunner to the Central Intelligence Agency. ${ }^{46}$ Donovan was joined by Princeton and Public Opinion Quarterly veteran DeWitt Clinton Poole, who headed up the COl's Foreign Nationalities Branch. ${ }^{47}$

Another major pillar of the wartime propaganda-research effort was founded in late 1941: the Army's Research Branch, headed by sociologist Samuel Stouffer. ${ }^{48}$ The main focus of the Research Branch was to study and analyze the American soldier, yielding the famous fourvolume study of the same name, published after the war with Carnegie Corporation support. 49 Stouffer's Army operation employed dozens of social scientists-mostly sociologists and psychologists-including Leonard Cottrell, Carl Hovland, Nathan Maccoby, Fred Sheffield, Arthur Lumsdaine, Irving Janis, Charles Dollard, Robin Williams, along with a host of consultants including Rensis Likert, Paul Lazarsfeld, Robert Merton, Hadley Cantril, and Frank Stanton. 50

The final entrant in the government's 1941 propaganda infrastructure was the short-lived Office of Facts and Figures, headed by Librarian of Congress Archibald MacLeish.51 MacLeish recruited Keith Kane, a Justice Department lawyer who had worked closely with Lasswell, to

43 See Sproule, Propaganda and Democracy, 186;

Ibid:; Alexander George, Propaganda Analysis (Evanston, IL: Row, Peterson \& Co., 1959), xv; and Bessner, Democracy in Exile, 134-137.

46 See George C. Chalou, ed., The Secrets War: The Office of Strategic Services in World War II (Washington, DC: National Archives and Records Administration, 1992); and Barry M. Katz, Foreign Intelligence: Research and Analysis in the Office of Strategic Services, 1942-1945 (Cambridge, MA: Harvard University Press, 1989).

47 US Office of Strategic Services, Foreign Nationalities Branch Files, 1942-1945 (Bethesda, MD: Congressional Information Service, 1988), viii.

48 Converse, Survey Research, 166; and Joseph W. Ryan, Samuel Stouffer and the GI Survey: Sociologists and Soldiers during the Second World War (Knoxville: University of Tennessee Press, 2013), 6. The Research Branch was established within the Army's Morale Division, which-after intervening name changes - was re-named the Information and Education Division. Ibid., 5. 
head up a Bureau of Intelligence, whose initial hires included political scientist Gabriel Almond. 52

\section{2}

\section{FIGURE SIX}

In the next year the wartime government's array of propaganda initiatives continued to expand - and transmogrify. The Office of War Information (OWI) was created mid-year by, in effect, absorbing two existing agencies: MacLeish's Office of Facts and Figures (OFF) as well as the foreign propaganda unit of William Donovan's Office of the Coordinator of Information (COI). ${ }^{53}$ The OWI was, in reality, two more-or-less autonomous agencies: the OFF-derived Domestic Branch, whose principal mission was to produce films, posters, and radio broadcasts to rally the American public; and a COl-derived Overseas Branch, targeting allies and enemies. To carry out both tasks, the OWI wings hired dozens of filmmakers, journalists, public relations professionals, and broadcasters-who, throughout the war, always outnumbered social scientists. ${ }^{54}$

Within the Domestic Branch, most scholarly activity was concentrated in Kane's Bureau of Intelligence, which was carried over from the OFF. For less than a year, the Bureau housed two competing survey-research operations, Rensis Likert's Division of Program Surveys (on loan), as well as an internal Polls Division led by commercial pollster Elmo Wilson.55 On Likert's side were Dorwin Cartwright, Jerome Bruner, Ruth Tolman, Eleanor Maccoby, Herbert Hyman, Daniel Katz, and Angus Campbell, among others.56 Wilson's unit was advised by Paul Lazarsfeld, Hadley Cantril, Frank Stanton, George Gallup, and Leonard Cottrell, with pollsters Harry Field and Elmo Roper providing operational support.57 The Domestic Branch's arrangement with the

52 Oren, Our Enemies, 140; Nils Gilman, Mandarins of the Future: Modernization Theory in Cold War America (Baltimore: Johns Hopkins University Press, 2003), 126.

53 See Allan M. Winkler, The Politics of Propaganda: The Office of War Information, 1942-1945 (New Haven, CT: Yale University Press, 1978); Sproule, Propaganda and Democracy, 187-188; and Converse, Survey Resarch, 172.

54 Winkler, Politics of Propaganda. See also Clayton R. Koppes and Gregory D. Black, "What to Show the World: The Office of War Information and Hollywood, 1942-1945," The Journal of American History 64, no. 1 (1977); and Sydney Weinberg, "What to Tell America: The Writers' Quarrel in the Office of War Information," The Journal of American History 55, no. 1 (1968).

55 See Converse, Survey Research, 171-74, 195-202, for a detailed account of the rivalry, which touched on methodological issues.

Marquis, "Social Psychologists," 116-17.

57 Converse, Survey Research, 171-72; and Marquis, "Social Psychologists," 118. 
Division of Program Surveys was ended in 1942, though-confusingly-some of Likert's staff stayed on with Wilson's Polls Division.58

The larger and better-funded Overseas Branch, headed by the poet Robert Sherwood, established a Central Intelligence Panel that employed psychologists Edwin Guthrie, Otto Klineberg, and Heinz Ansbacher, among others. ${ }^{59}$ The Overseas Branch, early the next year, also created a Bureau of Overseas Intelligence; psychologist Leonard Doob led the social scientists in the Bureau, assisted by political scientist Leo Rosten. ${ }^{60}$ Among the social scientists serving in Doob's unit were familiar names: Hans Speier, Geoffrey Gorer, E. R. Hilgard, Theodore Newcomb, Leo Lowenthal, and Arthur Schlesinger, Jr.61

The other half of William Donovan's Office of the Coordinator of Information-the portion responsible for "black," clandestine work-was absorbed into the Office of Strategic Services (OSS), established in $1942 .{ }^{62}$ Soon after, a unit within the Library of Congress, the Division of Special Information, was reconstituted as the OSS's Research and Analysis Branch. 63 It was within the Research and Analysis Branch (R\&A), led by psychoanalyst Walter Langer with large Washington and London offices, that most of the OSS social-scientific activity was centered. Among the scholars enlisted in the R\&A effort to analyze Axis propaganda were sociologists Edward Shils, Marion Levy, W. Phillips Davison, Morris Janowitz, Howard Becker, and Alex Inkeles, political scientists Saul Padover and Douglas Cater, psychologists Robert Tryon and John Gardner, economist Walt Rostow, anthropologists Ruth Benedict and Margaret Mead, historians Arthur Schlesinger, Jr. and H. Stuart Hughes, and a number of emigré scholars including Herbert Marcuse, Franz Neumann, and Sigmund Neumann.64 Harold Lasswell also consulted for the unit.65 Veterans of the Research and Analysis Branch-particularly among the sociologists and political scientists-would assume significant and overlapping propagandaresearch roles in the early Cold War.

58 Converse, Survey Research, 171-74. Even more confusingly, Wilson's unit, after Likert's arrangement was ended, was renamed as the OWI Surveys Division. See also Gosnell and David, "Instruction and Research," 566-69.

Marquis, "Social Psychologists," 118.

60

Marquis, "Social Psychologists," 118-19; Doob, "Utilization of Social Scientists," 657; and Peter Mandler, Return from the Natives: How Margaret Mead Won the Second World War and Lost the Cold War (New Haven: Yale University Press, 2013), 66-67.

Simpson, Science of Coercion, 191; Bessner, Democracy in Exile; Mandler, Return from the Natives, 72; Koppes and Black, "What to Show the World," 88; and Marquis, "Social Psychologists," 118-19.

64 Bessner, Democracy in Exile; Gilman, Mandarins in Exile, 124, 161; Simpson, Science of Coercion, 27; Marquis, "Social Psychologists," 121; and Cora Sol Goldstein, Capturing the German Eye: American Visual Propaganda in Occupied Germany (Chicago: University of Chicago Press, 2009), 8-9. 


\section{3}

\section{FIGURE SEVEN}

In 1943, a skeptical Congress scaled back some of the propaganda scaffolding that, over two preceding years, had been erected. The budget for the OWl's Domestic Branch was gutted, with Kane's Bureau of Intelligence abolished altogether. Elmo Wilson's polling division survived for one year before succumbing to budget cuts. ${ }^{66}$ Likewise, Harold Lasswell's Library of Congress operation was shuttered in 1943, with the Rockefeller Foundation opting against a new grant. ${ }^{67}$ The same year the FCC's Foreign Broadcast Intelligence Service (FBIS) saw its budget slashed; the analysis division that employed social scientists like Hans Speier was moved to the Washington headquarters of the OWI Overseas Branch. ${ }^{68}$ By 1944 most FBIS scholars (including Speier) had joined OWI, or left for other agencies. ${ }^{69}$

All the closures and cuts had the effect of triggering the migration of social scientists to other corners of the wartime propaganda campaign. The result-already common in the war's first two years - was more cross-fertilization among newly mobile social scientists. Lasswell's young Library of Congress staff, for example, formed something of a diaspora: Irving Janis left for Stouffer's Army Research Branch, Nathan Leites joined Speier at the FBIS, Morris Janowitz took a position at the OSS, and Heinz Eulau assumed a post at the OWI Overseas Branch.70 Lasswell himself consulted with each of the agencies, and more besides. ${ }^{71}$

One of Lasswell's other clients, the Psychological Warfare Branch, was formally created in late 1942 on General Dwight D. Eisenhower's orders, but began operations in 1943.72 In 1944, the Branch was reconstituted and expanded as the Psychological Warfare Division (PWD) under the umbrella of Eisenhower's Supreme Supreme Headquarters, Allied Expeditionary Force (SHAEF).73 A large cadre of social scientists joined the PWD in 1943 and 1944, some-like Janowitz, W. Phillips Davison, and Saul Padover-on loan from OSS, and others-including

Converse, Survey Research, 180-181.

Gary, Nervous Liberals, 171-72.

Bessner, Democracy in Exile; and Roop, Foreign Broadcast, 120-125.

69

Bessner, Democracy in Exile.

70

Converse, Survey Research, 235; Bessner, Democracy in Exile; and Simpson, Science of Coercion, 27.

71

Oren, Our Enemies and US, 139.

72

For a detailed account of the byzantine history of the Army's Psychological Warfare Branch, its dissolution in late 1942, and the delegation, in effect of psychological warfare to theater-specific Psychological Warfare Branch/Divisions, see Alfred H. Paddock, US Army Special Warfare: Its Origins: Psychological and Unconventional Warfare, 1941-152 (Washington: National Defense University Press, 1982), 8-12. 
Jerome Bruner, Edward Shils, John Riley, Henry Dicks, and Daniel Lerner-on staff.74 Together with the OSS Research and Analysis staff-of which there was considerable overlap-the veterans of the PWD would go on to take an outsized role in the early Cold War remobilization.

\section{4}

\section{FIGURE EIGHT}

In 1944 and 1945, the OSS, PWD, Army Research Branch, and OWI Overseas Branch continued to employ social scientists of all stripes - with the notable exception of economists, who tended to affiliate with institutions like Vannevar Bush's Office of Scientific Research and Development (particularly its Advanced Mathematics Panel) and the Planning Division of the War Production Board, rather than the government's persuasion agencies. ${ }^{75}$ One major propaganda-related effort was initiated in 1944, with the war's end in sight: the U.S. Strategic Bombing Survey. The Survey, designed to measure the effects of Allied bombing in Germany and Japan, contained a Morale Division headed by Rensis Likert. ${ }^{76}$ Among the social scientists employed by the Survey, which maintained operations in the post-war occupations, were Herbert Hyman, Gabriel Almond, Otto Klineberg, Daniel Katz, and Theodore Newcomb. ${ }^{77}$

\section{5 and 1946}

\section{FIGURE NINE and FIGURE TEN}

In 1945, and with accelerating pace the next year, the federal government began to dismantle its vast war machinery, including its many remaining propaganda and morale endeavors. The Army's Research Branch ceased operations in 1945, as did the OSS, PWD, and both branches of the OWI. The FBIS was shuffled around in the postwar years, and eventually absorbed into the Central Intelligence Agency.

74 Simpson, Science of Coercion, 27; Herman, Romance of American Psychology, 333; Mandler, Return from the Natives, 139; and Daniel Lerner, Sykewar: Psychological Warfare Against Germany, D-Day to VE-Day (New York: Stewart, 1949).

75 See Michael A. Bernstein, "American Economics and the National Security State, 1941-1953," Radical History Review, no. 63 (1995); Bernstein, A Perilous Progress: Economists and Public Purpose in Twentieth-Century America (Princeton: Princeton University Press, 2001); Jim Lacey, Keep from All Thoughtful Men: How U.S. Economists Won World War II (Annapolis, MD: Naval Institute Press, 2011); and Mark Guglielmo, "The Contribution of Economists to Military Intelligence During World War II," The Journal of Economic History 68, no. 1 (2008).

Converse, Survey Research, 174-180; Johnson and Nichols, "Social Psychologists' Expertise," 64-66; and Herman, Romance of American Psychology, 127.

77

Johnson and Nichols, "Social Psychologists' Expertise," 65; James H Capshew, Psychologists on the March (Cambridge: Cambridge University Press, 2010), 123-25; and Gilman, Mandarins of the Future, 126. 
When the social scientists returned to campus in 1945 and 1946, they arrived with their extensive networks of wartime contacts, together with on-the-cusp excitement over new methods and team-based research. Those contacts, crucially, were forged over years of peripatetic dynamism. A number of scholars served in more than one of the "big six" agencies: the Research and Analysis Branch (OSS), the Experimental Division (Library of Congress), the Overseas Branch (OWI), the Army's Research Branch, the Psychological Warfare Division, and the Foreign Broadcast Intelligence Service. Nearly 50 social scientists in this study's database served in two or more such roles. ${ }^{78}$ More tellingly, those who took on three or more posts would go on - nearly every one of them - to prominent positions in the early Cold War revival. ${ }^{79}$

\section{The Second Mobilization}

In the fall of 1947, the new Project RAND hosted a Conference of Social Scientists in New York. 80 The Air Force had established RAND the previous year within the Santa Monica-based Douglas Aircraft Company, and convened the conference to find a leader for its planned Social Sciences Division. ${ }^{81}$ The gathering was, among other things, a reunion: Nearly half the 35 participants were alumni of the wartime propaganda effort, including Bernard Berelson, Charles Dollard, Herbert Goldhamer, Ernst Kris, Harold Lasswell, Donald Marquis, Frederick Mosteller, Franz Neumann, Hans Speier, and Samuel Stouffer. 82 Propaganda and morale topics dominated the conference, with panels like "Aggression and Morale," "Attitudes and Opinions," and "Intelligence and Information." 83 And the transcript is pockmarked with confident, and strikingly martial, rhetoric about applying the lessons of war to the emerging Soviet conflict.

78 See the database: https://airtable.com/shrkJ6AFUPeBojCo2/tbIAUg0zbk21Be08f

79 Harold Lasswell (9 stints), Hadley Cantril (7), Jerome Bruner (6), Paul Lazarsfeld (6), Lloyd Free (6), Frank Stanton (4), Edward Shils (4), George Gallup (4), Daniel Katz (4), Geoffrey Gorer (4), Gordon Allport (3), Leonard Doob (3), E. R. Hilgard (3), Morris Janowitz (3), Otto Klineberg (3), Rensis Likert (3), DeWitt Clinton Poole (3), Leo Rosten (3), and Hans Speier (3). and Biological Sciences 27, no. 2 (1997), 241-42; David R. Jardini, "Out of the Blue Yonder: The Rand Corporation's Diversification into Social Welfare Research, 1946-1968" (Ph.D. dissertation, Carnegie Mellon University, 1996), 28-29; and Alex Abella, Soldiers of Reason: The Rand Corporation and the Rise of the American Empire (Boston: First Mariner Books, 2009), chap. 1; and Daniel Bessner, "Organizing Complexity: The Hopeful Dreams and Harsh Realities of Interdisciplinary Collaboration at the Rand Corporation in the Early Cold War: Organizing Complexity," Journal of the History of the Behavioral Sciences 51, no. 1 (2015): 34. 
Speier, tapped to lead the new division at the end of the conference, had been recommended to RAND by a wartime contact, Leo Rosten.84 Speier's Social Sciences Division (SSD) was established the next year in Washington, DC, and Speier soon recruited a number of World War II co-workers to its small staff: Joseph Goldsen, Philip Selznick, Abraham Kaplan, W. Phillips Davison, Alexander George, Herbert Goldhamer, and Nathan Leites. He also pulled in a large circle of wartime associates as SSD consultants, including Rosten, Gabriel Almond, Bernard Brodie, Harold Lasswell, Irving Janis, Ithiel de Sola Pool, Frederick Mosteller, and Edward Shils. ${ }^{85}$ Speier's roster of social scientists was drawn, almost exclusively, from the ranks of the wartime propaganda-research effort. 86

From 1947 through to the Korean armistice in 1953, the World War II propaganda and morale network was remobilized. RAND was a significant sliver of a much larger, loosely coordinated campaign to generate knowledge around what was increasingly labeled "psychological warfare." 87 A striking feature of this second mobilization is its resemblance to the first-if not, typically, through direct institutional continuity, then at least in personnel and modes of knowledge. In many ways the revived campaign was predicated on the lessons of the World War II effort; a cottage industry of reflective publications on the war effort appeared in the late 1940s, some skeptical and many others less so. 88

This early postwar echo was different in important ways from its World War II forerunner. In the war effort, as we have seen, social scientists left their campuses for direct employment in Washington and London. In the late 1940s, by contrast, most propaganda-research initiativesRAND was a notable exception-were based at universities and staffed by faculty. Much of the second campaign, moreover, was episodic and project-based, funded by contracts or grants. And the World War II initiatives were adjuncts to a comprehensive mobilization, with an early assist by the Rockefeller Foundation. Much of the late 1940s work was seeded by the military, to be sure, but funds and sponsorship came from other sources too, including the State Department, the Central Intelligence Agency, and the foundations. In fact, the foundations-

84 Bessner, "Organizing Complexity," 34; Bessner, Democracy in Exile. . As Bessner explains, an informal 1946 group comprising Rosten, Herbert Goldhamer, Olaf Helmer, Frederick Mosteller, W. Allen Wallis, Warren Weaver, and Samuel Wilks was convened to discuss which social scientists to invite to RAND.

85 Bessner, "Organized Complexity," 34; Bessner, Democracy in Exile; Oren, Our Enemies and US, 145; Janet Farrell Brodie, "Learning Secrecy in the Early Cold War: The RAND Corporation," Diplomatic History 35, no. 4 (2011): 656-657; Jardini, "Beyond the Blue Yonder," 38; and Conference on Methods for Studying the Psychological Effects of Unconventional Weapons (Santa Monica, CA: RAND Corporation, 1949).

In the course of Speier's tenure as SSD chief, Daniel Bessner could find only three staffers with no apparent war-related experience. Bessner, "Organized Complexity," 34.

88 See, for example, Gosnell and David, "Instruction and Research"; Lerner, Psykewar; Doob, "Utilization of Social Scientists"; Edward Shils, The Present State of American Sociology (Glencoe, IL: Free Press, 1948); Robert K Merton and Paul F. Lazarsfeld, eds., Studies in the Scope and Method of The American Soldier (Glencoe, IL: Free Press, 1950); and Harold D. Lasswell and Nathan Leites, eds., Language of Politics: Studies in Quantitative Semantics (Cambridge, MA: MIT Press, 1949). 
Rockefeller, Carnegie, and especially the reborn (and gigantic) Ford Foundation-played an outsized role in the second mobilization, albeit in close coordination with government agencies. Despite these differences, the two efforts bear a sibling resemblance. There were a few direct institutional inheritances in the second campaign, but more than anything it is the shared networks - the two generations of social scientists who labored against the Axis powers and then the Soviets - that bind the two periods.

The late 1940s backdrop, of course, was the Cold War. At the war's end and into 1946, tensions with the Soviet Union-a wartime ally, after all-were relatively muted. Indeed, a number of social scientists were active in the immediate postwar efforts to establish peaceful relations with the Soviets. ${ }^{89}$ But a cascade of setbacks and reactive escalations, beginning in 1947, restored the U.S. to a wartime posture. Harry Truman's spring 1947 vow to contain Soviet expansion was followed, later that year, by the National Security Act-legislation that, in effect, erected the infrastructure of the national security state (including the OSS-derived Central Intelligence Agency). Months after the 1948 Soviet-engineered coup in Czechoslovakia, the USSR began the Berlin Blockade, leading to the Western airlift. The North American Treaty Organization was formed the next year, and soon China "fell" to Mao Zedong's People's Liberation Army. In June 1950, North Korean forces invaded the South, setting off the four-year Korean conflict. The second mobilization of social scientists was tightly harnessed to the new bipolar conflict.

The Cold War propaganda-and-morale researchers were, crucially, at the center of the resurgent post-war social sciences. Indeed, there was a partial, but significant, overlap between them and the new social-scientific elite-the anthropologists, political scientists, sociologists, and social psychologists who constituted what came to be called the "behavioral sciences." The label itself was coined in the Cold War context at the Ford Foundation by veterans of the World War II propaganda campaign. 90 The cocksure scientism and choose-the-West assurance of the era's elite social science was anchored by the remobilized propaganda networks.

89 See Robert Gilpin, American Scientists and Nuclear Weapons Policy (Princeton, NJ: Princeton University Press, 2015), chap. 2. 


\section{7}

\section{FIGURE ELEVEN}

Vannevar Bush's wartime Office of Scientific Research and Development (OSRD) was formally shuttered in late 1947.91 Many of its coordinating functions were assumed by the military's Joint Research and Development Board (RDB), created the year before and which Bush also chaired.92 The next year the new agency created a Committee on Human Resources, charged with research and development on, among other things, "group leadership and morale, public opinion and propaganda, analyses of culture."93 The Michigan psychologist Donald Marquis was named the Committee's chair, and four panels were established, led by Lyle Lanier, Robert Thorndike, Philip Hauser, and Charles Dollard.94 Dollard, by 1948, had ascended to the Carnegie Corporation presidency, and also served as a trustee of the RAND Corporation. His panel, Human Relations and Morale, included Hans Speier, Alexander Leighton, and Carl Hovland. ${ }^{95}$ Among the consultants for Dollard's panel were a familiar cast of names: Elmo Wilson, Harold Lasswell, Harry Alpert, Clyde Kluckhohn, Rensis Likert, and brother John Gardner (also at Carnegie). ${ }^{96}$ The Human Resources Committee, as a whole, was charged with issuing funding recommendations for military social science support; in 1949 alone, the committee disbursed $\$ 7.5$ million, a comparatively large sum, though dwarfed by the military's much larger natural science outlays. 97

The Dollard brothers' Carnegie Corporation underwrote, around this time, Harold Lasswell's content analysis project at Stanford's Hoover Institute. The project, Revolution and the Development of International Relations (RADIR), was a reincarnation of Lasswell's Library of Congress operation, though targeting the Soviets 98 Established in late 1946, the project began

91 Daniel Lee Kleinman, Politics on the Endless Frontier: Postwar Research Policy in the United States (Durham: Duke University Press, 1995), 117-18. See Solovey, Shaky Foundations, 68-72, for an overview National Security State," Diplomatic History 17, no. 3 (1993): 404-5. Near the end of the war, Marquis had served as an aide in Bush's OSRD. Rebecca S. Lowen, Creating the Cold War University: The Transformation of Stanford (Berkeley: University of California Press, 1997); Solovey, Shaky Foundations, 68; and Simpson, Science of Coercion, 57

Research and Development Board: History and Functions (Washington: The National Military Establishment, 1948), iii.

Ibid., 4.

Simpson, Science of Coercion, 58.

Needell, “'Truth is Our Weapon,"” 407; and Simpson, Science of Coercion, 59.

Ibid., 58; Solovey, Shaky Foundations, 69-70.

Hemant Shah, The Production of Modernization: Daniel Lerner, Mass Media, and The Passing of Traditional Society (Philadelphia: Temple University Press, 2011), 27, 57-68; 
operations the next year with sociologist Daniel Lerner installed as research director.99 Lerner was joined by Ithiel de Sola Pool, a Lasswell student and veteran of the Library of Congress initiative. 100 The trio published a number of book-length studies, and Lerner and Lasswell collaborated on a massive 1951 tome, The Policy Sciences. ${ }^{101}$ E. R. Hilgard, Saul Padover, and Pool helped edit the volume, whose authors include Herbert Hyman, Alex Bavelas, Paul Lazarsfeld, Rensis Likert, Margaret Mead, Robert Merton, Edward Shils, and Hans Speier. ${ }^{102}$

Carnegie also seeded Harvard's Russian Research Center (RRC), which began operating in 1947 under the leadership of anthropologist Clyde Kluckhohn and with close ties to the new CIA. ${ }^{103}$ Among the Center's staffers were sociologists Alex Inkeles, Raymond Bauer, and Barrington Moore.104 The Center, among a number of other contract-research projects, conducted interviews of Soviet refugees as part of an Air Force-sponsored study of the Soviet social system in the early 1950 s. ${ }^{105}$

\section{8}

\section{FIGURE TWELVE}

In the fall of 1948, the Ford Foundation - willed 90 percent of Ford Motor Company's stock and poised for a re-launch as a national institution in line with its enormous resources-convened a Study Committee of academics to chart a course for the foundation. The committee was chaired by attorney $\mathrm{H}$. Rowan Gaither, a veteran of the OSRD/MIT Rad Lab who led Project RAND's 1948 recharter as the RAND Corporation and served as RAND's chair through 1951.106 Even before the Study Committee met, Gaither solicited the advice of Hans Speier, who would

99 Ibid.

100 Lowen, Creating the Cold War University, 204-8.

101 Harold D. Lasswell, C. Easton Rothwell, and Daniel Lerner, The Comparative Study of Elites (Stanford, CA: Stanford University Press, 1952); and Ithiel de Sola Pool, Harold D. Lasswell, and Daniel Lerner, The 'Prestige Papers': A Survey of Their Editorials (Stanford, CA: Stanford University Press, 1953); and Daniel Lerner and Harold D. Lasswell, eds., The Policy Sciences (Stanford, CA: Stanford University Press, 1951).

102 Ibid.

103 Scott Lucas, Freedom's War: The American Crusade against the Soviet Union (New York: New York University Press, 1999), 114; David C. Engerman, Know Your Enemy: The Rise and Fall of America's Soviet Experts (New York: Oxford University Press, 2009), 46-48; and Ellen Condliffe Lagemann, The Politics of Knowledge: The Carnegie Corporation, Philanthropy, and Public Policy (Chicago: University of Chicago Press, 1992), 172-75.

104 Engerman, Know Your Enemy, 50.

105 See David Engerman, "The Rise and Fall of Wartime Social Science: Harvard's Refugee Interview Project, 1950-1954," in Cold War Social Science: Knowledge Production, Liberal Democracy, and Human Nature, ed. Mark Solovey and Hamilton Cravens (New York: Palgrave Macmillan, 2012).

106 Jardini, "Beyond the Blue Yonder," 72. 
go on to play a central role in Ford's social science initiatives. ${ }^{107}$ The key social scientist Study Committee member was Donald Marquis, who helped engineer a surprisingly robust role for the social sciences in the committee's 1949 report, with an explicit and aggressive role for propaganda coordination. ${ }^{108}$ Marquis, together with Speier, chaired a 1951 search for a director of the Foundation's Area Five, devoted to what Marquis had dubbed the "behavioral sciences."109 They selected library scientist Bernard Berelson-who Speier had come to know in shared FBIS service-and the three scholars spent the fall drafting a plan for what they now called the Behavioral Sciences Program (BSP). ${ }^{110}$ Among those formally consulted for the plan were Robert Merton, Samuel Stouffer, Herbert Simon, Paul Lazarsfeld, Ithiel de Sola Pool, Allen Wallis, Talcott Parsons, Nathan Leites, and Harold Lasswell. ${ }^{111}$ The Behavioral Sciences Program was formally established in 1953, and over its lifespan -the Program was shuttered in 1957 due to trustees' skittish response to Congressional scrutiny of foundations-was easily the most important and generous funder of social science research in the period. ${ }^{112}$

During the BSP planning period, Speier hatched a plan for a Ford-funded, university-affiliated psychological warfare center.113 Working with Marquis and Berelson, Speier developed his proposal for an Institute of International Communications. In early 1952, Ford trustees approved funds to plan the center, which was established as the Research Program in International Communications within MIT's Center for International Studies (CENIS) the next year (with CIA funds secretly passed through Ford; see below).114

Also in 1948, the Army created the Operations Research Office (ORO) at Johns Hopkins University. ${ }^{115}$ Studies by ORO, according to an official military history, "included a three-volume basic reference work for psychological warfare, manuals for use by psychological warfare operators in specific countries, an analysis and grouping of sample leaflets from World War II and Korea to develop classification schemes, and a large amount of field operations research in

\footnotetext{
107 Jefferson Pooley and Mark Solovey, "Marginal to the Revolution: The Curious Relationship between Economics and the Behavioral Sciences Movement in Mid-Twentieth-Century America," History of Political Economy 42, Sup. 1 (2010): 204.

108

109 Pooley, "A 'Not Particularly Felicitous Phrase."”

110 Bessner, Democracy in Exile.

111 Pooley and Solovey, "The Curious Case," 219-20.

112 Solovey, Shaky Foundations, chap. 3.

113 Bessner, Democracy in Exile.

114 Ibid.

115 Joy Rohde, Armed with Expertise: The Militarization of American Social Research during the Cold War (Ithaca, NY: Cornell University Press, 2013), 23; and William Thomas, Rational Action: The Sciences of Policy in Britain and America, 1940-1960 (Cambridge, MA: MIT Press, 2015), 149.
} 
Korea." 116 Over the next five years, and primarily in the Korean context, a number of prominent social scientists consulted for the ORO: Morris Janowitz, Harold Lasswell, Daniel Lerner, Leo Lowenthal, Joseph Klapper, Wilbur Schramm, and Philip Mosely. 117

\section{9}

\section{FIGURE THIRTEEN}

In early 1949, the RAND Corporation's Social Science Division convened a conference on "methods for studying the psychological effects of unconventional weapons." 118 The three-day conference brought together RAND staffers like Hans Speier, W. Philips Davis, Herbert Goldhamer, Abraham Kaplan, Nathan Leites, Philip Selznick with consultants including Harold Lasswell, Irving Janis, Leo Rosten, and Bernard Brodie. ${ }^{119}$ The aim of the gathering was to consider the psychological impact of "unconventional" weapons like atomic bombs, but also gamma rays, satellite-delivered rockets, and "economics weapons" like the distribution of counterfeit currency. ${ }^{120}$ The transcript records a detailed, and occasionally surreal, discussion of "communication acts" before, during, and after the use of such weapons. ${ }^{121}$

The same year, Frankfurt School scholar Leo Lowenthal was tapped to lead a new Program Evaluation Branch for the Voice of America (VOA), the overseas broadcast unit housed in the State Department with roots stretching back to the 1942 Office of Facts and Figures.122 Lowenthal, a veteran of Paul Lazarsfeld's Bureau of Applied Social Research, recruited other Bureau personnel to the VOA, including Marjorie Fiske, Joseph Klapper, and Ralph White-and secured the services of pollster Elmo Roper. ${ }^{123}$ In 1950, Lowenthal awarded a contract to the Bureau to conduct audience surveys in six Middle Eastern countries. The Bureau, in turn, brought in Stanford's Daniel Lerner to lead the study, which was published in 1958 as the

\footnotetext{
116 Paddock, US Army Special Warfare, 116-17.

117 Glander, Origins of Mass Communications, 64-65; and Bruce Cumings, "Boundary Displacement: Areas Studies and International Studies During and After the Cold War," in Universities and Empire: Money and Politics in the Social Sciences during the Cold War, ed. Christopher Simpson (New York: New Press, 1998), 185.

118 Conference on Methods.

119 Ibid., ii-iii.

120 lbid., 3-17.

121 Ibid., 29-35.

122 Leo Lowenthal, An Unmastered Past: The Autobiographical Reflections of Leo Lowenthal, ed. Martin Jay (Berkeley: University of California Press, 1987), chap. 3; Shah, Production of Modernization, 82.

Ibid.
} 
modernization-theory classic The Passing of Traditional Society-without, however, disclosing its origins or funding. ${ }^{124}$

In 1952, at the suggestion of Lazarsfeld, Lowenthal established a Committee on International Communication Research, as part of the professional association that survey researchers and pollsters had created in 1947, the American Association of Public Opinion Research (AAPOR). The committee's membership was chock full of wartime veterans and other figures prominent in early Cold War propaganda research: Raymond Bauer, Leo Crespi, W. Phillips Davison, Alexander George, Alex Inkeles, Morris Janowitz, Daniel Lerner, and John Riley, among others. ${ }^{125}$ An extraordinary special issue of the Public Opinion Quarterly-the cross-disciplinary field's crossroads since the late 1930s-was published based on the committee's meetings, edited by Lowenthal. ${ }^{126}$ The issue contained over 20 articles on all aspects of psychological warfare, authored by the committee members.

Back in 1949, the Air Force established another social science-oriented research entity, the Human Resources Research Institute (HRRI). ${ }^{127}$ Directed by sociologist Raymond Bowers, the Institute sponsored the Russian Research Center's refugee interview project and was especially active during the Korean War.128 The Institute, for example, commissioned a trio of social scientists, Wilbur Schramm, John Riley, and John Pelzel, to travel to post-occupation Seoul to interview South Korean civilians and freed prisoners-of war. ${ }^{129}$ Schramm and Riley-both committed Cold Warriors-soon published a hot-blooded popular account, The Reds Take a City. 130

124 Ibid., 83-100; and Daniel Lerner, The Passing of Traditional Society (New York: Free Press, 1958).

125 "Proceedings of the Committee on International Communications Research," Public Opinion Quarterly 16, no. 4 (1952-1953): 705-8.

126

Leo Lowenthal, ed., Special Issue on International Communications Research, Public Opinion Quarterly 16, no. 4 (19521953).

Robin, Making of the Cold War Enemy, 50, 87.

Engerman, "Rise and Fall," 30.

Robin, Making the Cold War Enemy, 74-80.

John W. Riley and Wilbur Schramm, The Reds Take a City (New Brunswick, NJ: Rutgers University Press, 1951). 


\section{0}

\section{FIGURE FOURTEEN}

In 1950 Harvard and MIT administrators, supported by the State Department, organized a secretive, three-month gathering at MIT, Project TROY.131 The intensive effort was centered on developing a workable psychological-warfare plan, and involved over 20 full-time academic participants. The roster of social scientists includes many of the usual suspects: Jerome Bruner, Alex Bavelas, Clyde Kluckhohn, Donald Marquis, Max Millikan, and Hans Speier. ${ }^{132}$ The group's top-secret report, issued the next year, did not mince words: "Like a rifle, an information program becomes a significant instrument in the achievement of our national objectives only when designed as one component in a political 'weapon system."'133 Project TROY proved influential, and among other impacts, the initiative was the direct impetus behind MIT's Center for International Studies (CENIS), whose initial working name was Troy Plus. ${ }^{134}$ Max Millikan, who spent the year between TROY and MIT at the CIA, was appointed to lead CENIS in 1952.

Donald Marquis, also in 1950, convened a conference of social scientists under the auspices of his RDB Human Resources Committee, which issued a call for more research on the psychology of propaganda. ${ }^{135}$ In the same year, RAND sent a number of SSD staffersincluding Herbert Goldhamer, Alexander George, and W. Philips Davison-to Korea to study the psychology of prisoners of war. 136

With the left gaining traction in a number of European countries, the CIA-disguised through sham foundations-created the Congress for Cultural Freedom in 1950, the opening front in what would become a much broader intellectual offensive.137 Among the many social scientists involved in the organization's leadership were Edward Shils, Daniel Bell, and Marion Levy. 138

\footnotetext{
131 Needell, “'Truth is Our Weapon””; and Engerman, Know Your Enemy, 48-49.

132 Needell, “'Truth is Our Weapon,” 400-401.

133 Quoted in Ibid., 399.

134 Gilman, Mandarins of the Future, 158; Oren, Our Enemies and US, 148; and Engerman, Know Your Enemy, 49-51.

135 Needell, “'Truth is Our Weapon,” 404-5.

136 Bessner, Democracy in Exile, 205.

137 Peter Coleman, The Liberal Conspiracy: The Congress for Cultural Freedom and the Struggle for the Mind of Postwar Europe (New York: Free Press, 1989); and Frances Stonor Saunders, The Cultural Cold War: The CIA and the World of Arts and Letters (New York: The New Press, 2013). 


\section{1}

\section{FIGURE FIFTEEN}

With the Korean War in full swing, a cross-agency initiative was formed, the Psychological Strategy Board (PSB), to coordinate the government's many competing "psychological operations." 139 A number of social scientists were recruited to provide advice to the Board as official consultants, and the roster of names is, by now, predictable: Hadley Cantril, Clyde Kluckhohn, Philip Selznick, Harold Lasswell, Daniel Lerner, Morris Janowitz, Hans Speier, Alexander Leighton, Gabriel Almond, and W. Philip Davison-all veterans of the World War II propaganda-and-morale campaign. ${ }^{140}$

The Army's Human Resources Research Office (HumRRO) also got underway in 1951, housed at George Washington University. ${ }^{141}$ The Office was inspired by, and intended to model, Samuel Stouffer's World War II Research Branch, though with a narrower mission centered on "psychotechnology": "research into training methods, Gl motivation and morale, and psychological warfare." 142

\section{2 and 1953}

\section{FIGURE SIXTEEN and FIGURE SEVENTEEN}

In 1952 Hans Speier's vision for a Ford-funded, university-affiliated research center on international communications was finally coming to fruition. That summer Ford's Behavioral Sciences Program issued a $\$ 875,000$ grant to MIT's Center for International Studies, to house a Research Program in International Communication. (The funds were later revealed to come from the ClA.) ${ }^{143}$ Speier was appointed chair of the Program's planning committee, whose members were already well-acquainted: Jerome Bruner, Harold Lasswell, Paul Lazarsfeld, Wallace Carroll, and Edward Shils.144 They met six times and, in early 1953, issued their report.145 "The conflict between the Communists and the free worlds," they wrote, "is of decisive importance to the balance of power and the future character of our civilization." The

\footnotetext{
139 Lucas, Freedom's War, 130; and Oren, Our Enemies and US.

140 Herman, The Romance of American Psychology, 130; Lucas, Freedom's War, 114; and Oren, Our Enemies and US, 145.

141 Lyons, Uneasy Partnership, 141-2; and Rohde, Armed with Expertise, 23.

142 Robin, Making of the Cold War Enemy, 53.

143 Bessner, Democracy in Exile.

144 Ibid.; Simpson, Science of Coercion, 82.

145 See the abridged, published version: "A Plan of Research in International Communication," World Politics 6, no. 3 (1954).
} 
struggle is for "the hearts and minds of men both in the Soviet empire and in the vast 'neutral' reas of the world which lie outside either sphere of influence."146

And so our story ends where it began, and with the same protagonists. The International Communication program began operations in 1953, with Ithiel de Sola Pool appointed director - and Daniel Lerner his deputy. ${ }^{147}$

\section{Conclusion}

This argument for a second mobilization of scholar-cum-propaganda-analysts is built on a large body of secondary literature (as well as an exhausting parade of acronyms). While a number of secondary accounts do nod to the World War II roots of Cold War propaganda research, the claim has not received sustained attention. Yet the evidence has been hiding in plain sight.

One explanation for the historiographical dormancy is the turn to disciplinarity that has arguably characterized the U.S. social sciences since the 1960s. ${ }^{148}$ The growing insularity of the disciplines has, as its mirror, siloed historiographies: Published work in the history of the postwar social sciences has tended to focus on a single field, in conversation with small clusters of other self-identified historians of the same discipline. The problem is that elite social science, in the first two decades after the war, was shot through with cross-disciplinary ventures-including those preoccupied with questions of persuasion and propaganda. By peering through disciplinary lenses that have subsequently sharpened, the cross-disciplinary character of early postwar social science is often overlooked. The result is a fragmented historiography. 149

The challenge is compounded in the propaganda-and-morale case, owing to the curious importance of "communications research." In the run-up to, during, and after the war, communications research was a cross-disciplinary enterprise, with close ties to the world of public opinion research. In the middle-third of the 20th century, the field was populated by political scientists, sociologists, and social psychologists who, however, maintained their disciplinarity identities. The scholars who worked on communication topics, many of them, were drawn to the field by the exigencies of funding (including, but not limited to, the World War II and Cold War contexts). Once the funding dried up in the early 1960s, many researchers

146 Ibid., 365.

147 Shah, Production of Modernization, 27.

148 On the increasing discipline-centered evolution of U.S. social sciences since the 1960s, see Crowther-Heyck, "Patrons of the Revolution," 440-446; and Roger E. Backhouse and Philippe Fontaine, "Toward a History of the Social Sciences," in A Historiography of the Modern Social Sciences, ed. Backhouse and Fontaine (Cambridge: Cambridge University Press, 2016), 222. 
turned to other topics. At the same time, beginning in the 1950s and with gathering force, a would-be discipline of communication was established within pre-existing journalism schools and speech departments. ${ }^{150}$ Exiled to the professional-school margins of the U.S. university, the low-status field has claimed the cross-disciplinary period as a usable past. The field's mnemonic hagiography has been supplemented by more rigorous and critical work in recent decades, but these histories tend to cast an anachronistic net of disciplinarity over the post-war decades-before anything like an organized discipline had emerged. Narrowly framed and segregated off from the mainline disciplines, this history has generally failed to register with historians of these other fields. The co-evolution of propaganda-related scholarship and crossdisciplinary communications research has, as a result, suffered neglect. And the full scope of the early Cold War remobilization is the case in point.

For the field of communications research, the Cold War re-mobilization had important consequences. In the immediate postwar years, the field and its handful of champions had turned their attention to domestic questions. By the late 1940s, on the Cold War's cusp, the field's published literature had come to emphasize that mass media have only limited effectsthat media influence is happily negligible.151 But the heated up contest with the Soviets yoked communications research to propaganda design for the new national security state, all rather suddenly. In both published and classified reports, many scholars turned to the international context and adopted the language of "psychological warfare" across a range of projects. 152 The result was the awkward coexistence of overseas persuasion work and published reassurance on the domestic front. After the Korean armistice, the argument for "limited effects" returned in force, even as some of the claim's leading proponents worked on post-colonial modernization projects for the national security state. The same scholars charged with designing effective propaganda, in other words, were also concluding - in public venues like the mid- to late-1950s mass culture debate-that the effects of media are happily negligible. Communications research in the postwar decades was, in effect, packaged twice: for the frontstage scholarly and public-intellectual arenas, as evidence that media effects were minimal; and for the backstage Pentagon and State Department patrons, as sophisticated guidance for making propaganda work.

The paper's broader point is that the leading champions of the behavioral sciences movement were the same figures re-mobilized for Cold War propaganda and morale research. Most had

150 See Jefferson Pooley and Elihu Katz, "Further Notes on Why American Sociology Abandoned Mass Communication Research," Journal of Communication 58, no. 4 (2008).

151 Jefferson Pooley, "Fifteen Pages That Shook the Field: Personal Influence, Edward Shils, and the Remembered History of Mass Communication Research," Annals of the American Academy of Political and Social Science 608, no. 1 (2006).

152 Christopher Simpson, Science of Coercion: Communication Research and Psychological Warfare, 1945 - 1960 (New York: Oxford University Press, 1994); Timothy R. Glander, Origins of Mass Communications Research during the American Cold War (Mahwah, NJ: Lawrence Erlbaum, 2000); and Ron Robin, The Making of the Cold War Enemy: Culture and Politics in the Military-Intellectual Complex (Princeton: Princeton University Press, 2009). 
worked together in World War II and, many of those, in the sampling-based public opinion research community of the late 1930s. The claim is that they were mobilized not once, but twice. 


\section{Bibliography}

"A Plan of Research in International Communication.” World Politics 6, no. 3 (1954): 358-377.

Abella, Alex. Soldiers of Reason: The Rand Corporation and the Rise of the American Empire. Boston: First Mariner Books, 2009.

Acland, Charles R. "Screen Technology, Mobilization, and Adult Education in the 1950s ." In Patronizing the Public: American Philanthropy's Transformation of Culture, Communication, and the Humanities, edited by William Buxton, 261-79. Lanham, MD: Lexington Books, 2009.

Backhouse, Roger E., and Philippe Fontaine. "Toward a History of the Social Sciences." In A Historiography of the Modern Social Sciences, edited by Roger E. Backhouse and Philippe Fontaine, 184-233. Cambridge: Cambridge University Press, 2016.

Bernstein, Michael A. A Perilous Progress: Economists and Public Purpose in TwentiethCentury America. Princeton: Princeton University Press, 2001.

Bernstein, Michael A. "American Economics and the National Security State, 1941-1953." Radical History Review 1995, no. 63 (1995): 9-26. doi:10.1215/01636545-1995-63-9.

Bessner, Daniel. Democracy in Exile: Hans Speier and the Rise of the Defense Intellectual. Ithaca: Cornell University Press, 2018.

- - - "Organizing Complexity: The Hopeful Dreams and Harsh Realities of Interdisciplinary Collaboration at the Rand Corporation in the Early Cold War: Organizing Complexity." Journal of the History of the Behavioral Sciences 51, no. 1 (2015): 31-53. doi:10.1002/ jhbs.21699.

Bowen, William G, Harold T Shapiro, and Princeton Conference on Higher Education. Universities and their leadership, 1998. http://public.eblib.com/choice/ publicfullrecord.aspx? $\mathrm{p}=4562464$.

Brett, Judith. Australian Liberals and the Moral Middle Class From Alfred Deakin to John Howard. Cambridge: Cambridge University Press, 2003.

Brodie, Janet Farrell. "Learning Secrecy in the Early Cold War: The RAND Corporation." Diplomatic History 35, no. 4 (2011): 643-70. doi:10.1111/j.1467-7709.2011.00971.x.

Bryson, Lyman, ed. The Communication of Ideas. New York: Harper, 1948. 
Buxton, William J. "Reaching Human Minds: Rockefeller Philanthropy and Communications, 1935-1939." In The Development of the Social Sciences in the United States and Canada: The Role of Philanthropy, edited by Theresa R. Richardson and Donald Fisher, 177-92. Stamford, Conn: Ablex Pub. Corp, 1999.

- - - "The Political Economy of Communications Research." In Information and Communication in Economics, edited by Robert E. Babe, 147-75. Boston: Kluwer Academic Publishers, 1994.

Cantril, Hadley. The Human Dimension: Experiences in Policy Research. New Brunswick, NJ: Rutgers University Press, 1967.

Capshew, James H. Psychologists on the March. Cambridge: Cambridge University Press, 2010.

Chalou, George C., ed. The Secrets War: The Office of Strategic Services in World War II. Washington, DC: National Archives and Records Administration, 1992.

Childs, Harwood L. "The First Editor Looks Back." Public Opinion Quarterly 21, no. 1 (1957): 713. doi:10.1086/266680.

Clausen, John A. "Research on the American Soldier as a Career Contingency." Social Psychology Quarterly 47, no. 2 (1984): 207-13. doi:10.2307/3033951.

Coleman, Peter. The Liberal Conspiracy: The Congress for Cultural Freedom and the Struggle for the Mind of Postwar Europe. New York: Free Press, 1989.

Conference of Social Scientists: September 14 to 19, 1947-New York. Santa Monica, CA: RAND Corporation, 1948.

Conference on Methods for Studying the Psychological Effects of Unconventional Weapons. Santa Monica, CA: RAND Corporation, 1949.

Converse, Jean M. Survey Research in the United States: Roots and Emergence, 1890-1960. Berkeley: University of California Press, 1987.

Crowther-Heyck, Hunter. Herbert A. Simon: The Bounds of Reason in Modern America. Baltimore: Johns Hopkins University Press, 2005.

- - . "Patrons of the Revolution: Ideals and Institutions in Postwar Behavioral Science." Isis 97, no. 3 (2006): 420-46. doi:10.1086/508075. 
Culbert, David. "The Rockefeller Foundation, the Museum of Modern Art Film Library, and Siegfried Kracauer, 1941." Historical Journal of Film, Radio and Television 13, no. 4 (1993): 495-511. doi:10.1080/01439689300260381.

Cumings, Bruce. "Boundary Displacement: Areas Studies and International Studies During and After the Cold War." In Universities and Empire: Money and Politics in the Social Sciences during the Cold War, edited by Christopher Simpson, 159-88. New York: New Press, 1998.

Doob, Leonard W. "The Utilization of Social Scientists in the Overseas Branch of the Office of War Information." American Political Science Review 41, no. 4 (1947): 649-67. doi: $10.2307 / 1950646$.

Engerman, David. "The Rise and Fall of Wartime Social Science: Harvard's Refugee Interview Project, 1950-1954." In Cold War Social Science: Knowledge Production, Liberal Democracy, and Human Nature, edited by Mark Solovey and Hamilton Cravens, 26-43. New York: Palgrave Macmillan, 2012.

Engerman, David C. Know Your Enemy: The Rise and Fall of America's Soviet Experts. New York: Oxford University Press, 2009.

Erb, Claude Curtis. "Nelson Rockefeller and United States-Latin American Relations, 1940-1945." Ph.D. dissertation, Clark University, 1982.

Fisher, Donald. Fundamental Development of the Social Sciences: Rockefeller Philanthropy and the United States Social Science Research Council. Ann Arbor: University of Michigan Press, 1993.

Gall, Johannes C. "An 'Art of Fugue' of Film Scoring: Hanns Eisler' s Rockefeller FoundationFunded Film Music Project (1940-1942) ." In Patronizing the Public: American Philanthropy's Transformation of Culture, Communication, and the Humanities, edited by William Buxton, 123-51. Lanham, MD: Lexington Books, 2009.

Gary, Brett. "Communication Research, the Rockefeller Foundation, and Mobilization for the War on Words, 1938-1944." Journal of Communication 46, no. 3 (1996): 124-48. doi: 10.1111/j.1460-2466.1996.tb01493.x.

- - - The Nervous Liberals: Propaganda Anxieties from World War I to the Cold War. New York: Columbia University Press, 1999.

George, Alexander. Propaganda Analysis. Evanston, IL: Row, Peterson \& Co., 1959. 
Gilman, Nils. Mandarins of the Future: Modernization Theory in Cold War America. Baltimore: Johns Hopkins University Press, 2003.

Gilpin, Robert. American Scientists and Nuclear Weapons Policy. Princeton, NJ: Princeton University Press, 2015. https://doi.org/10.1515/9781400875467.

Glander, Timothy R. Origins of Mass Communications Research during the American Cold War. Mahwah, NJ: Lawrence Erlbaum, 2000.

Goldstein, Cora Sol. Capturing the German Eye: American Visual Propaganda in Occupied Germany. Chicago: University of Chicago Press, 2009.

Gosnell, Harold F., and Moyca C. David. "Instruction and Research: Public Opinion Research in Government." American Political Science Review 43, no. 3 (1949): 564-72.

Graves, Harold N. War on the Short Wave. New York: Foreign Policy Association, 1941.

Guglielmo, Mark. "The Contribution of Economists to Military Intelligence During World War II." The Journal of Economic History 68, no. 1 (2008): 109-50. doi:10.1017/ S0022050708000041.

Herman, Ellen. The Romance of American Psychology: Political Culture in the Age of Experts. Berkeley: University of California Press, 1996.

Hounshell, David. "The Cold War, RAND, and the Generation of Knowledge, 1946-1962." Historical Studies in the Physical and Biological Sciences 27, no. 2 (1997): 237-67. doi: 10.2307/27757779.

Hyman, Herbert H. Taking Society's Measure: A Personal History of Survey Research. New York: Russell Sage Foundation, 1991.

Jardini, David R. "Out of the Blue Yonder: The Rand Corporation's Diversification into Social Welfare Research, 1946-1968." Ph.D. dissertation, Carnegie Mellon University, 1996.

Johnson, Blair T., and Diana R. Nichols. "Social Psychologists' Expertise in the Public Interest: Civilian Morale Research During World War II." Journal of Social Issues 54, no. 1 (1998): 53-77. doi:10.1111/0022-4537.00055.

Katz, Barry M. Foreign Intelligence: Research and Analysis in the Office of Strategic Services, 1942-1945. Cambridge, MA: Harvard University Press, 1989.

Kleinman, Daniel Lee. Politics on the Endless Frontier: Postwar Research Policy in the United States. Durham: Duke University Press, 1995. 
Koppes, Clayton R., and Gregory D. Black. "What to Show the World: The Office of War Information and Hollywood, 1942-1945." The Journal of American History 64, no. 1 (1977): 87-105. doi:10.2307/1888275.

Lacey, Jim. Keep from All Thoughtful Men: How U.S. Economists Won World War II. Annapolis, MD: Naval Institute Press, 2011.

Lagemann, Ellen Condliffe. The Politics of Knowledge: The Carnegie Corporation, Philanthropy, and Public Policy. Chicago: University of Chicago Press, 1992.

Lasswell, Harold D., and Nathan Leites, eds. Language of Politics: Studies in Quantitative Semantics. Cambridge, MA: MIT Press, 1949.

Lasswell, Harold D., C. Easton Rothwell, and Daniel Lerner. The Comparative Study of Elites. Stanford, CA: Stanford University Press, 1952.

Latham, Michael E. Modernization as Ideology: American Social Science and "Nation Building" in the Kennedy Era. Chapel Hill: University of North Carolina Press, 2000.

Lazarfeld, Paul F., and Frank N. Stanton, eds. Communications Research, 1948-1949. New York: Harper, 1949.

Lazarsfeld, Paul F. "An Episode in the History of Social Research." In The Intellectual Migration: Europe and America, 1930-1960, edited by Bernard Bailyn and Donald Fleming, 270-337. Cambridge, MA: Harvard University Press, 1969. https://doi.org/10.4159/harvard. 9780674334120.

Lerner, Daniel. Sykewar: Psychological Warfare Against Germany, D-Day to VE-Day. New York: Stewart, 1949.

- - - The Passing of Traditional Society. New York: Free Press, 1958.

Lerner, Daniel, and Harold D. Lasswell, eds. The Policy Sciences. Stanford, CA: Stanford University Press, 1951.

Lowen, Rebecca S. Creating the Cold War University: The Transformation of Stanford. Berkeley: University of California Press, 1997.

Lowenthal, Leo. An Unmastered Past: The Autobiographical Reflections of Leo Lowenthal. Edited by Martin Jay. Berkeley: University of California Press, 1987.

- - ed. "Special Issue on International Communications Research." Public Opinion Quarterly 16, no. 4 (1953 1952). 
Lucas, Scott. Freedom's War: The American Crusade against the Soviet Union. New York: New York University Press, 1999.

Lyons, Gene M. The Uneasy Partnership: Social Science and Federal Government in the Twentieh Century. New York: Russell Sage Foundation, 1969.

Mandler, Peter. Return from the Natives: How Margaret Mead Won the Second World War and Lost the Cold War. New Haven: Yale University Press, 2013.

Marquis, D. G. "Social Psychologists in National War Agencies." Psychological Bulletin 41, no. 2 (1944): 115-26. doi:10.1037/h0056072.

Merton, Robert K, and Paul F. Lazarsfeld, eds. Studies in the Scope and Method of The American Soldier. Glencoe, IL: Free Press, 1950.

Morrison, David E. The Search for a Method: Focus Groups and the Development of Mass Communication Research. Luton, UK: University of Luton Press, 1998.

Needell, Allan A. “'Truth Is Our Weapon': Project TROY, Political Warfare, and GovernmentAcademic Relations in the National Security State." Diplomatic History 17, no. 3 (1993): 399-420. doi:10.1111/j.1467-7709.1993.tb00588.x.

Ohmer, Susan. George Gallup in Hollywood. New York: Columbia University Press, 2012.

Oren, Ido. Our Enemies and US: America's Rivalries and the Making of Political Science. Ithaca, NY: Cornell University Press, 2013.

Ortiz Garza, José Luis. "The Early Days of Survey Research in Latin America." In The Early Days of Survey Research and Their Importance Today, edited by Hannes Haas, Hynek Jarabek, and Thomas Peterson, 143-58. Vienna: Braumüller, 2012.

Paddock, Alfred H. US Army Special Warfare: Its Origins: Psychological and Unconventional Warfare, 1941-152. Washington: National Defense University Press, 1982.

Politics as Rational Action: Essays in Public Choice and Policy Analysis. Place of publication not identified: Springer, 2013.

Pool, Ithiel de Sola, Harold D. Lasswell, and Daniel Lerner. The 'Prestige Papers': A Survey of Their Editorials. Stanford, CA: Stanford University Press, 1953.

Pooley, Jefferson. "An Accident of Memory: Edward Shils, Paul Lazarsfeld and the History of American Mass Communication Research." Ph.D. Dissertation, Columbia University, 2006. 
- - -. "Fifteen Pages That Shook the Field: Personal Influence, Edward Shils, and the Remembered History of Mass Communication Research." Annals of the American Academy of Political and Social Science 608, no. 1 (2006): 130-56. doi: 10.1177/0002716206292460.

Pooley, Jefferson D. "A 'Not Particularly Felicitous' Phrase: A History of the 'Behavioral Sciences' Label." Serendipities: Journal for the Sociology and History of the Social Sciences 1, no. 1 (2016): 38-81.

Pooley, Jefferson D., and Socolow, Michael. "Checking Up on The Invasion from Mars: Hadley Cantril, Paul Lazarsfeld, and the Making of a Misremembered Classic." International Journal of Communication 7 (2013): 1920-48.

Pooley, Jefferson, and Elihu Katz. "Further Notes on Why American Sociology Abandoned Mass Communication Research." Journal of Communication 58, no. 4 (2008): 767-86. doi:10.1111/j.1460-2466.2008.00413.x.

Pooley, Jefferson, and Michael Socolow. "War of the Words: The Invasion from Mars and Its Legacy for Mass Communications Scholarship." In War of the Worlds to Social Media: Mediated Communication in Times of Crisis, edited by Joy Elizabeth Hayes, Kathleen Battles, and Wendy Hilton-Morrow, 35-56. New York: Peter Lang, 2013.

Pooley, Jefferson, and Mark Solovey. "Marginal to the Revolution: The Curious Relationship between Economics and the Behavioral Sciences Movement in Mid-Twentieth-Century America." History of Political Economy 42, no. Sup.1 (2010): 199-233. doi: 10.1215/00182702-2009-077.

"Proceedings of the Committee on International Communications Research." Public Opinion Quarterly 16, no. 4 (1953 1952): 705-8.

RAND Corporation. Research Careers at the RAND Corporation. RAND Corporation, 2015. doi: 10.7249/CP530-2015-01.

Reich, Cary. The Life of Nelson A. Rockefeller: Worlds to Conquer, 1908-1958. New York: Doubleday, 1996.

Research and Development Board: History and Functions. Washington: The National Military Establishment, 1948.

"Research Projects and Methods the Motion Picture." Journal of Educational Sociology 13, no. 5 (1940): 307-12. doi:10.2307/2262645. 
Riley, John W., and Wilbur Schramm. The Reds Take a City. New Brunswick, NJ: Rutgers University Press, 1951.

Robin, Ron. The Making of the Cold War Enemy: Culture and Politics in the Military-Intellectual Complex. Princeton: Princeton University Press, 2009.

Rohde, Joy. Armed with Expertise: The Militarization of American Social Research during the Cold War. Ithaca, NY: Cornell University Press, 2013.

Roop, Joseph E. Foreign Broadcast Information Service History Part I: 1941-1947. Langley, VA: Central Intelligence Agency, 1969.

Rutkoff, Peter M., and William B. Scott. New School: A History of the New School for Social Research. New York: Free Press, 2009.

Ryan, Joseph W. Samuel Stouffer and the Gl Survey: Sociologists and Soldiers during the Second World War. Knoxville: University of Tennessee Press, 2013.

Saunders, Frances Stonor. The Cultural Cold War: The CIA and the World of Arts and Letters. New York: The New Press, 2013.

Schramm, Wilbur, ed. Communications in Modern Society. Urbana: University of Illinois Press, 1948.

- - , ed. Mass Communications. Urbana: University of Illinois Press, 1949.

Shah, Hemant. The Production of Modernization: Daniel Lerner, Mass Media, and The Passing of Traditional Society. Philadelphia: Temple University Press, 2011.

Shils, Edward. The Present State of American Sociology. Glencoe, IL: Free Press, 1948.

Shils, Edward A., and Morris Janowitz. "Cohesion and Disintegration in the Wehrmacht in World War II.” Public Opinion Quarterly 12, no. 2 (1948): 280-315. doi:10.1086/265951.

Simpson, Christopher. Science of Coercion: Communication Research and Psychological Warfare, 1945 - 1960. New York: Oxford University Press, 1994.

Smith, Bradley F. "The American Road to Central Intelligence." Intelligence and National Security 12, no. 1 (1997): 1-20. doi:10.1080/02684529708432396.

Solovey, Mark. Shaky Foundations: The Politics-Patronage-Social Science Nexus in Cold War America. New Brunswick, NJ: Rutgers University Press, 2015. 
Sproule, J. Michael. Propaganda and Democracy: The American Experience of Media and Mass Persuasion. New York, NY: Cambridge University Press, 1997.

Stouffer, Samuel A. The American Soldier. 4 vols. Princeton, NJ: Princeton University Press, 1949.

Thomas, William. Rational Action: The Sciences of Policy in Britain and America, 1940-1960. Cambridge, MA: MIT Press, 2015.

US Office of Strategic Services, Foreign Nationalities Branch Files, 1942-1945. Bethesda, MD: Congressional Information Service, 1988.

Wasson, Haidee. "Hollywood Bypass: MoMA, the Rockefeller Foundation, and New Circuits of Cinema." In Patronizing the Public: American Philanthropy's Transformation of Culture, Communication, and the Humanities, edited by William Buxton, 101-21. Lanham, MD: Lexington Books, 2009.

Weinberg, Sydney. "What to Tell America: The Writers' Quarrel in the Office of War Information." The Journal of American History 55, no. 1 (1968): 73-89. doi:10.2307/1894252.

Winkler, Allan M. The Politics of Propaganda: The Office of War Information, 1942-1945. New Haven, CT: Yale University Press, 1978. 